\title{
Who gives pain relief to children?
}

\author{
R L Spedding, D Harley, F J Dunn, L A McKinney
}

\begin{abstract}
Objective-To compare pre-hospital parental administration of pain relief for children with that of the accident and emergency (A\&E) department staff and to ascertain the reason why pre-hospital analgesia is not being given.
\end{abstract}

Design/methods-An anonymous prospective questionnaire was given to parents/guardians of children $<17$ years. The children were all self referred with head injuries or limb problems including burns. The first part asked for details of pain relief before attendance in the $A \& E$ department. The second part of the questionnaire contained a section for the examining doctor and triage nurse to fill in. The duration of the survey was 28 days. Results-Altogether 203 of 276 (74\%) of children did not receive pain relief before attendance at the $A \& E$ department. Reasons for parents not giving pain relief included $57 / 203(28 \%)$ who thought that giving painkillers would be harmful; 43/ $203(21 \%)$ who did not give painkillers because the accident did not happen at home; and 15/203 (7\%) who thought analgesia was the responsibility of the hospital. Eighty eight of the $276(32 \%)$ did not have any painkillers, suitable for children, at home. A\&E staff administered pain relief in $189 / 276(68 \%)$.

Conclusions-Parents often do not give their children pain relief before attending the A\&E department. Parents think that giving painkillers may be harmful and often do not have simple analgesics at home. Some parents do not perceive that their child is in pain.

Parents require education about appropriate pre-hospital pain relief for their children.

(F Accid Emerg Med 1999;16:261-264)

Keywords: pain relief; children; pre-hospital; parents

There have been many studies assessing levels of analgesia in hospitalised children. ${ }^{1-4}$ They have been critical of medical and nursing staff for giving inadequate analgesia to children in hospital..$^{2-4}$ To our knowledge, no studies have been performed to assess the use of simple analgesia in children before hospital attendance in the UK (internet and Medline search, November 1998). Our experience was that injured children were not receiving any analgesia before attending the accident and emergency (A\&E) department. The study was performed to find out where deficiencies in the administration of analgesia occur and the reasons why analgesia is not given.

\section{Methods}

The questionnaire (fig 1) was devised after discussion with staff from the hospital and the local university (Magee). Further modifications were made over a 48 hour period, to the satisfaction of both medical and nursing staff. The questionnaire was then piloted for a full week (without further modification) to encourage staff participation. The questionnaire was administered over a 28 day period in spring 1998. One questionnaire was distributed per child.

The questionnaire was in two parts. The first was filled in by a parents or guardians of the child attending the A\&E department. All children were $<17$ years old. Children entered in the study were self referred with head injuries and limb problems including lacerations and burns. Children attending by ambulance or directly from school or with abdominal, chest, or dermatology conditions were excluded from the study.

The first part of the survey ascertained the age of the child, the occupation of the parents/ guardians, the delay in presentation, and if there were painkillers suitable for children at home. When pain relief was given before $A \& E$ department attendance, the type and the dose of analgesic were documented. The reason for analgesia not being given was recorded.

The second part of the questionnaire was completed by A\&E department staff. This included the type, dose, and timing of administration of analgesia. The problem, whether a limb injury, burn, laceration, or head injury and the result of radiography (if required) was recorded. The diagnosis and whether the child required a general anaesthetic were documented. The authors checked each proforma every day against the $\mathrm{A} \& \mathrm{E}$ department ledger and completed any unfinished second part of the proformas.

\section{SETTING}

The A\&E department serves an urban/rural catchment of more than 250000 . In the year, the busiest periods with children are summer and autumn; $40 \%$ of the 43500 new patient attendances are children. The A\&E department records are not computerised. $\mathrm{A} \& \mathrm{E}$ department staff nurses are authorised to give pain relief at triage. Triage is performed by either a senior staff nurse or doctor. Oral medication given at triage included paracetamol (elixir or tablets), ibuprofen syrup, or codeine $8 \mathrm{mg} /$ paracetamol $500 \mathrm{mg}$ (for children 12 years and older). Topical $1 \%$ lignocaine soaks were used on wounds before treatment. Analgesics were stored in a locked cupboard adjacent to the triage desk. 


\section{Survey on pain relief in children}

THANK YOU FOR TAKING THE TIME TO COMPLETE THIS ANONYMOUS SURVEY AS IT WILL HELP US TO PROVIDE BETTER PAIN RELIEF FOR ALL YOUNG PEOPLE

Age of child _ years _ months (for example 01 years and 05 months)

Occupation of guardians/parents and

Did you give your child something for pain?

Yes/no

If yes: the name of the painkiller

the dose given

If no: what was the reason? Please tick the appropriate boxes

Had no painkillers at home

Accident did not happen at home

Child refused

Did not know the dose

Afraid that it would be wrong or harmful

On the advice of chemist

The hospital should give the medications

Because of advice given in TV or magazine

If so which programme/magazine?

Other reason: please state

How long from the time of the accident/onset of pain until attendance at the accident and emergency department?

$$
\begin{gathered}
\text { days }- \text { hours and }- \text { minutes } \\
\text { (for example } 0 \text { days, } 1 \text { hour, and } 30 \text { minutes) }
\end{gathered}
$$

What painkillers do you have at home?

Doctor to fill in: If painkiller given, record type and dose

At triage

On examination

Before $x$ ray/suturing

Before admission

For home

$\begin{array}{llll}\text { Sutures } & \text { Yes/no } & \text { Burn } & \text { Yes/no } \\ \text { Head injury } & \text { Yes/no } & & \\ \text { Limb problem } & \text { Yes/no } & \text { Limb injury } & \text { Yes/no } \\ x \text { Ray } & \text { Yes/no } & \text { Fracture } & \text { Yes/no } \\ \text { Required a general anaesthetic } & & \text { Yes/no }\end{array}$

Figure 1 Questionnaire.
$17 / 73(23 \%)$ received medication at infrequent intervals before attending the department, creating suboptimal levels of analgesia.

Paracetamol was given by $64 / 73$ (88\%) parents, whereas staff used paracetamol in $145 /$ $189(77 \%)$ cases. Hospital staff gave 10 children non-steroidal analgesia (ibuprofen or diclofenac sodium) but only four children received non-steroidal analgesia at home (table 1). No child was given rectal analgesia. Three children received pre-hospital aspirin. No child was given too much pain relief by a parent.

Altogether 203 out of 276 (74\%) children did not receive any analgesics before attending the A\&E department. Reasons for parents not giving pain relief included 57/203 (28\%) who believed that giving painkillers would be harmful, for example they thought that it would make the child drowsy; $43 / 203$ (21\%) did not give painkillers because the accident did not happen at home; and 15/203 (7\%) thought it was "the hospital's responsibility" (table 2). Eighty eight of the 276 (32\%) parents, when asked to list the painkillers kept at home, had no analgesics suitable for children.

Other reasons for withholding pain relief were given in $48 / 203(23 \%)$. In 25 cases the parents considered that the child was either "not in pain", "not sore", "not serious", "stopped crying", or "did not ask". In eight cases parents gave the reason as "panic" for not giving pain relief. Seven children "refused" painkillers from their parent but five subsequently accepted them from hospital staff. In six cases pain relief was not given on telephone advice from a health centre. Two parents stated that painkillers were not given on the basis of first aid training, two stated they were "awaiting an $x$ ray diagnosis", and two stated it was "too soon" to give pain relief.

\begin{tabular}{|c|c|c|}
\hline Analgesia & At home & $\begin{array}{l}\text { At AE E } \\
\text { department }\end{array}$ \\
\hline \multicolumn{3}{|l|}{ Paracetamol } \\
\hline Elixir & 45 & 101 \\
\hline Tablets & 19 & 38 \\
\hline $\begin{array}{l}\text { Paracetamol } 500 \mathrm{mg} / \text { codeine } \\
\text { phosphate } 8 \mathrm{mg}\end{array}$ & 2 & 18 \\
\hline $\begin{array}{l}\text { Combination oral paracetamol + } \\
\text { local anaesthetic }\end{array}$ & - & 6 \\
\hline \multicolumn{3}{|l|}{ Ibuprofen } \\
\hline Elixir & 1 & 8 \\
\hline Tablets & 3 & 1 \\
\hline Diclofenac sodium & - & 1 \\
\hline Aspirin & 3 & - \\
\hline Opiate & - & 3 \\
\hline Local anaesthetic & - & 13 \\
\hline Total & 73 & 189 \\
\hline
\end{tabular}

Table 1 Types of analgesia given

Table 2 Reasons for withholding analgesia (in 203/276 patients)

\section{Results}

During the study period, 842 children attended the A\&E department and $645(77 \%)$ fitted the criteria for the study. Due to pressure of work within the department, 276/645 (43\%) of eligible parents received a questionnaire. One questionnaire was distributed per child. All 276 questionnaires given to parents were completed. No parent or guardian refused to take part in the study. Parents/guardians who had trouble reading were offered assistance by $A \& E$ staff, but usually preferred help from their literate children. The mean age of the children was 8.06 years (range $0.75-16.66$ ).

Seventy three of the $276(26 \%)$ children received pain relief before attendance. These included $6 / 73(8 \%)$ where analgesia was administered more than 12 hours before

\begin{tabular}{|c|c|}
\hline & No \\
\hline No analgesics at home & 88 (32\%) \\
\hline Afraid of harm & 57 \\
\hline Accident did not occur at home & 43 \\
\hline Child did not need/not sore & 19 \\
\hline Panic/straight to $\mathrm{A} \& \mathrm{E}$ & 18 \\
\hline Hospital responsibility & 15 \\
\hline Child refused & 12 \\
\hline Uncertain of dose & 5 \\
\hline
\end{tabular}
attendance at the $A \& E$ department. A further 
Table 3 Employment and those who received pre-hospital analgesia

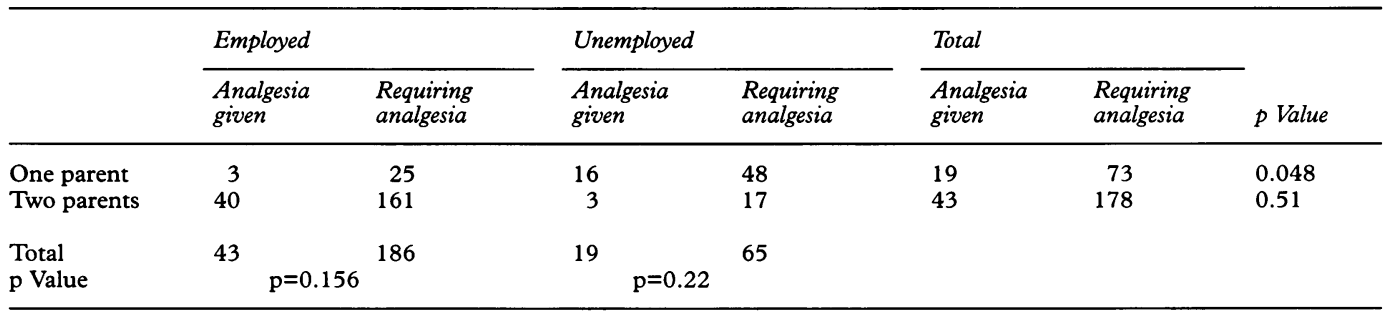

Parental occupation was listed in $251 / 276$ (91\%); 178/251 (71\%) were from two parent families and $73 / 251(29 \%)$ from single parent families. Sixteen out of $48(33 \%)$ of the single parent families who were unemployed and $3 / 17(17 \%)$ of the two parent families who were unemployed gave analgesia. There was no significant difference between those parents who gave analgesia in the unemployed single and two parent families $\left(\chi^{2}\right.$ test, $\left.p=0.22\right)$, nor employed one and two parent families $\left(\chi^{2}\right.$ test, $\mathrm{p}=0.156)$. There was a significant difference ( $\chi^{2}$ test, $p=0.048$ ) between one parent employed and unemployed families who gave prehospital analgesia to their children (table 3).

Hospital staff gave medications to $189 / 276$ $(69 \%)$ of the children; 71 (38\%) received pain relief at triage (table 4 ). This included mainly children who had received no medication before attending hospital but also included a small number who had received medication more than 12 hours before attending hospital. In three cases the child required intravenous analgesia. Forty of the 189 children (21\%) received medication solely for home; $36 / 189$ $(19 \%)$ received medication for home as well as in the $A \& E$ department.

\section{Discussion}

Hospital staff are increasingly aware of pain felt by children. Pain management is being improved by the development of tools, for example the five faces scale, to aid in the assessment of children's pain. ${ }^{1-356}$ The age group for which the tools are accurate is being defined. ${ }^{7-9}$ Hospital staff are still giving inadequate analgesia to children. ${ }^{40-12}$ Friedland et al showed that children were receiving both suboptimal and delayed analgesia even in paediatric A\&E departments. ${ }^{1011}$

This study shows that $68 \%$ of children are receiving appropriate analgesia in the $A \& E$ department, which is similar to the $63 \%$ in the retrospective review of pain management of three $A \& E$ departments (including a paediatric and a combined department). ${ }^{4}$

Our study shows that $74 \%$ of children are not receiving any pain relief before they attend the $A \& E$ department. By contrast, in a large

Table 4 Medication given by hospital staff

\begin{tabular}{|c|c|c|c|c|}
\hline Given at & $\begin{array}{l}\text { In } A \mathcal{E} E \\
\text { department }\end{array}$ & $\begin{array}{l}\text { AEE E department } \\
\text { and home }\end{array}$ & $\begin{array}{l}\text { Discharged } \\
\text { home }\end{array}$ & Total \\
\hline Triage & 49 & 22 & 0 & 71 \\
\hline Examination & 23 & 3 & 0 & 26 \\
\hline Before investigation & 40 & 11 & 0 & 51 \\
\hline Admission & 1 & 0 & 0 & 1 \\
\hline Discharge & - & - & 40 & 40 \\
\hline Total & 113 & 36 & 40 & 189 \\
\hline
\end{tabular}

study from Nigeria, $91 \%$ of children had received medication (often inappropriate) before attending hospital. Children travel many miles to hospital before paying for medical attention. ${ }^{13}$ Ease of access and free health care may alter perception of parental responsibility.

Many parents are under the misapprehension that giving pain relief could be harmful. ${ }^{14}$ This may be because the distinction between major and minor injury has become blurred by portrayal in the media. The "nil by mouth" rule is only relevant in major trauma or in children requiring a general anaesthetic. Administration of oral analgesia does not effect the management of the majority of limb fractures. Fractures requiring manipulation are done semielectively and so the ingestion of small amounts of oral analgesia is less relevant.

The properties of paracetamol are misunderstood. Some parents consider it to be a sedative ${ }^{14}$ and subsequently withheld it in head injury. Others are unaware that paracetamol is an analgesic as well as an antipyretic. Unfortunately, despite extensive media coverage, three children were still given aspirin.

Parents may misinterpret when a condition is painful or underestimate the amount of pain experienced by the child, for example a child may not receive pain relief for bruising. ${ }^{12}{ }^{15} \mathrm{~A}$ single dose of analgesia is given in most soft tissue injuries. This may imply that parents are unaware of the natural course of soft tissue injuries. In this study, in $31 \%$ of children, parents provided infrequent analgesia. Parents appear to be unsure of the correct dosage interval for oral analgesics. ${ }^{12}{ }^{14-16}$ Other parents appear to "await an $x$ ray diagnosis" and then give pain relief when subsequent radiography is found to be abnormal.

Some parents consider that the A\&E department should provide all treatment, including pain relief, thereby abdicating responsibility for first aid measures in the home.

The present NHS provides simple oral analgesia, free to all children under the age of 18 . It is inexplicable why one third of parents were found not to keep any analgesics suitable for children at home.

A wide range of reasons were given (table 2) as to why $74 \%$ of children did not receive pain relief before attending hospital. Regular analgesia was given in a minority of children who had received pre-hospital pain relief. Hospital staff gave analgesia to $68 \%$ of children but only $38 \%$ was administered at triage. From the results of this study, both parents and hospital staff need more education about simple analgesia for children. 
An education programme about paediatric analgesia for surgical ward staff has been found to change both staff and also parental management. ${ }^{17}$ This involved training staff how to recognise pain in children, how to select appropriate and adequate pain relief for that child and how to provide instruction to parents. At the same time, new written advice was devised to go with discharge medication. A similar programme would be useful in $A \& E$ departments. Trained staff would be more likely to give analgesia appropriate to the child's pain and to provide parents with information about pain assessment, medication, and management in children.

\section{Conclusions}

Parents are not giving their children pain relief before attending the A\&E department. There was often a considerable delay, before attendance, while the child remained without adequate analgesia. Some parents are uncertain when their child is in pain. Often parents do not keep painkillers suitable for children at home. In many cases, parents are unsure of when to give analgesia and are afraid that giving pain relief may be harmful.

Hospital staff need to be trained to recognise and appropriately treat pain in children. Trained staff will be able to educate parents about pain recognition and management in children.

Conflict of interest: none.

Funding: none.
1 Mather L, Mackie J. The incidence of post-operative pain in children. Pain 1983;15:271-82.

2 Twycross A. Nurses' perceptions of pain in children. Paediatric Nursing 1997;9:16-19.

3 Selbst SM, Clark $M$. Analgesic use in the emergency department. Ann Emerg Med 1990;19:1010-13.

4 Petrack EM, Christopher NC, Kriwinsky J. Pain management in the emergency department: patterns of analgesic utilisation. Pediatrics 1997;99:711-4.

5 Royal College of Paediatrics and Child Health. Prevention and control of pain in children. A manual for health professionals. (Based on the finding of a workshop of the Royal College of Paediatrics and Child Health, chaired by D Southlege of Paediatrics and Child Health, chaired

6 Hodges C. Easing children's pain. Nursing Times 1998;94: 55-7.

7 Wong DL, Baker CM. Pain in children; comparison of assessment scales. Pediatric Nursing 1988;14:9-17.

8 Keck JF, Gerkensmeyer JE, Joyce BA, et al. Reliability and validity of the faces and word descriptor scales to measure procedural pain. $\mathcal{F}$ Pediatr Nurs 1996;11:368-74.

9 Ferguson L, Beattie TF. Measurement of pain in children in the emergency department. $\mathcal{f}$ Accid Emerg Med 1997;15: 140.

10 Friedland LR, Pancioli AM, Duncan KM. Pediatric emergency department analgesia practice. Pediatr Emerg Care 1997;13:103-6.

11 Friedland LR, Kulick RM. Emergency department analgesic use in pediatric trauma victims with fractures. Ann Emerg Med 1994;23:203-7.

12 Zacharias $M$, Watts $D$. Pain relief in children. $B M f$ 1998;316:1552.

13 Orisakwe OE, Orish CN, Aka PA. Prevalence of parental medication on children before going to the hospital. Trop Doct 1994;24:182-3.

14 Gedaly-Duff V, Ziebath D. Mother's management of adenoid-tonsillectomy pain in 4 to 8 year olds: a preliminary study. Pain 1994;57:293-9.

15 Bellman MH, Paley CE. Pain control in children - parents underestimate children's pain. BMF 1993;307:1563.

16 Finley GA, McGrath PJ, Forward SP, et al. Parents' management of children's pain following "minor" surgery. Pain 1996;64:83-7.

17 Sepponen $\mathrm{K}$, Ahonen $\mathrm{R}$, Kokki $\mathrm{H}$. The effects of a staff training program on the treatment practices of postoperative pain in children under 8 years. Pharmacy World and Science 1998;20:62-70. 